\title{
APPROPRIATING JOHN PAUL II'S LABOREM EXERCENS IN PEDAGOGICAL WORK
}

\section{Juan Rafael G. Macaranas De La Salle-College of Saint Benilde, Philippines}

\begin{abstract}
The Laborem Exercens (1981) offers a philosophy, a rational discourse, that can serve as a timeless guide in examining work. Starting with a brief review of John Paul II's personalistic view of the human person under the aspect of work, this paper expounds on work in pedagogy. Since work is always a personal action, it follows that the whole person, body and spirit, participates in it, whether manual or intellectual. Work is a personal action; the one who carries it out is a person, a conscious and free subject. The philosophy puts to light the teacher's work purpose, by itself and in relation to society, and its contributions to the teacher's well-being. The tenets espoused by the encyclical, such as upholding just wage, can be used as a lens in rethinking teachers' objective realities. Fictionalized mini cases are presented to illustrate some of the real challenges that teachers deal with.

An educator's work is a daunting and noble task. Pedagogical work is not just a job; it is a venue for self-fulfillment. Laborem Exercens reminds us that teachers particularly express the nature and dignity of the human person by their work. Moreover, through pedagogy, the teacher can perfect him/herself in solidarity and participation with others.
\end{abstract}

\section{INTRODUCTION}

John Paul II is not just a moral and intellectual icon but also a phenomenal worker. As Karol Wojtyla, his being "the worker," is described in detail by George Weigel $(2005,53)$. He worked for years as a poverty-stricken manual laborer-under the wartime German occupation of his country and was identified with peasants and workers by Tadd Szulc $(1996,16)$. Understandably, he is among the philosophers whose concept of the person is uniquely related to work. In a world situation full of forces that put so much emphasis on progress and social advancement that also caused human sufferings and moral questions, his call brought human dignity to the center stage. He advanced the notions of the rights of the human person, the primacy of the worker, and the subordination of work to man, among others.

John Paul II shared the idea that "the person is a concrete, rational and free 
subject who is capable of all those activities that reason and freedom can make possible" (Aguas 2014, 290-291). Further, the rational soul gives man his spiritual capacities or faculties of intelligence and will. Through reason and will, the spirituality of man is actualized, and through it, man realizes himself (Aguas 2009, 51). The whole human person, being both spirit and body, is important in comprehending the human person.

Human nature is the basis of personhood, while subjectivity has its foundation on the existential manifestation of man as seen in action, experience, and existence (Mara 2007, 95). The personalist is to understand man "in his innerness, his unique and irreducible character" (Mara, 87). The person resides in the innerness of man. The manifestation of subjectivity is from the internal going to the external realm. Subjectivity is rooted in the person. All actions done by the subject derives from the person.

The encyclical Laborem Exercens (On Human Work, 1981) ${ }^{1}$ provided the world with a profound and important reflection on work. Modern workdays and workloads require heavy personal commitments of time and energy. Work remains the most significant area of our lives. The stakes attendant to it is indeed high. One specific work is teaching; the teacher is a worker who is tasked with educating the youth. This paper shall highlight the essential themes of the encyclical that are relevant to the work of teachers - hence the term pedagogical work. A teacher is a human person at work, and the encyclical is a lens that can be used in appreciating the teacher's work in the hope that it will add more meaning to teaching and learning in and beyond the classroom.

\section{LABOREM EXERCENS PRINCIPLES}

\section{The Human Person}

John Paul II places the human person as the starting point in approaching social questions. Regardless of the many definitions of man as there are philosophical nuances, conventional or unconventional, he believes that the human person can serve as the guiding light for comprehending human work. ${ }^{2}$

The human being towers above the material world. Personhood means participation and perfection in the light of the divine mind. Behind his intense concern for each real, concrete, historical person lies a powerful humanism rooted in faith and in his penetrating philosophy of the human person, which was already embodied in his earlier encyclical, Redemptor Hominis (1979, Nos. 13-14). ${ }^{3}$ His constant call for the dignity and honor of a person expressed his personalistic attitude towards the human person. As Thomas Doyle $(1987,6)$ in his article, The Dignity of the Human Person in the thought of John Paul II said, "The human person is the only creature created by God for its own sake. Everything else is created for humanity, and nothing else is equal to the human person for the person alone reflects the reality of God."

Going back a bit farther, Vatican II formally acknowledged this growing sense of the dignity of the human person in the consciousness of contemporary man in Dignitatis Humanae (1965, No. 1). The Church perceived it in the joys and hopes 
and the griefs and anxieties of men in the era. This awakening, underlying the expectations of the contemporary world, was welcomed as a challenge that the Church found important to properly respond to (Gaudium et Spes 1965, No. 1). Fittingly, in 1981, John Paul II proposed that human labor held the key to understanding and overcoming the then growing world crisis (Baum 1986, 233), which he carefully explained in his Encyclical on Labor.

From the Laborem Exercens, I extracted four characteristics of the human person that are most relevant to this topic. First, the human person as the Image of God (Imago Dei), tracing back the fundamental truth about work as essentially linked to the person in the context of the mystery of creation. "God created man in his own image, in the image of God, He created him, male and female, he created them" (Genesis 1:26-31; 2:7-25; 5:1-3). Being in the image of God, the human person not only possesses the dignity of a person but also shares God's dignity as well. A person is not just something, but someone. Moreover, we can only see the human person in God if we have the insight to see God in the human person. The person created in God's image is the key to understanding the essential meaning of one's existence and the nature and value of one's being, including in relation to work. Personhood means participation and perfection "in the light of the divine mind."

The second is the human person as a corporeal and spiritual being. The human person is a rational being, a thinking being, composed of body and soul. The Church used to treat the human person as a spiritual being. The traditional emphasis was on the soul or spiritual aspects of believers. John Paul II refuted this by emphasizing both body and soul. The human person is a substantial unity of body and soul, citing the biblical account expressing this reality in this symbolic language, "then the Lord God formed man of dust from the ground, and breathed into his nostrils, the breath of life, and the person became a living being" (Genesis: 2:7). The Compendium of the Social Doctrine of the Church elaborates on how the human being exists as a whole person: corpore et anima unus (Catholic Church, 2005, 64). The unity of soul and body is so profound that one must consider the soul to be the form of the body. Because of its spiritual soul, the body, made of matter, becomes a living human body, spirit, and matter in human persons. They are not two natures united, but rather their union forms a single nature.

The third is man as a sharer in the Dignity of the Image of God. The human body shares in the dignity of God. It is a human body precisely because it is animated by a spiritual soul, and it is the whole human person that is intended to become a sharer in the dignity of the Image of God. Ronald Lawler (1982, 32), summarizing the Pope's Christian personalism, put it this way:

Man is the possessor of a nature that uniquely mirrors God. He possesses an intelligence that is, in principle, capable of knowing and becoming all things. He has a will and an ability to love and to relate himself to each person and to everything of worth in ways that bind together in his boundless subjectivity the whole world in a special way.

The fourth is the human person as a unique personal being. The human person is a unique personal subject in the visible world. The human person is the self. 
Everyone is with body and soul, but each one is distinct and set off from every other being, never repeated, never repeatable. No two people, even twins, are the same. Aguas $(2009,56)$ elaborates on this as follows:

The person, because of his reason and free will, is a sui juris. Therefore, he is his own master and cannot be determined by the external impressions and messages from the external world. In addition to this, his personality is alteri incommunicabilis; it cannot be transferred to somebody else. In other words, the human person is not just a master of himself; he is, at the same time, a unique and unrepeatable entity.

Everyone is unique and distinct. Each one is different and diverse. No one can decide for others. Nobody can substitute the will for others. Aguas (2014, 293) further explains this:

In the study of the human person, one must always consider one's concrete experience. Through self-cognition, a man sees a basic fact in his own existence. He experiences himself as a whole subject, a dynamic subject that is unique and unrepeatable. This basic and concrete experience ultimately reveals what man really is, a unique and whole subject.

In order to appreciate John Paul II's philosophy of human work, his personalistic approach must be understood first. These human attributes underlie his concept of human work. The man of John Paul II is the human person who finds fulfillment realization to the fullest only through work.

\section{The Human Person as a Worker}

Work can be seen in its objective and subjective senses. Work in the objective sense refers to the whole range of products and instruments that the human person's work produces, including simple products and technology. Simple products of labor are food and clothing, and minerals extracted from the earth and seas (LE, Nos. 5 and 6). Technology is seen as "a set of instruments devised by a person's intelligence which he uses to facilitate, perfect, accelerate and augment his work." ASIMO (Advanced Step in Innovative Mobility) and Baymax are examples of this. Nonphysical products, such as services, would be another work category.

Work in the subjective sense refers to the human person who works. Farmers and cooks produce food. Scientists, engineers, and craftsmen produce instruments for work. Doctors, nurses, technicians work for hospitals to care for the sick. Janitors, plumbers, carpenters, and a whole range of workers build and maintain buildings that house people and services. Teachers are instrumental for schools to produce graduates trained to produce products and technologies or give services of all kinds. These people work hard to fulfill their needs and the needs of their families.

The personalist view asserts that considering subjective and objective work, the 
person working is more valuable and more important than the object produced. The human beings tower above the "material world." This is because the human person is gifted with intelligence and free will. People ought to enjoy dominion over their actions and, consequently, over their work. Humans have higher ethical value at work.

\section{Just Wage, among other Rights of Workers}

John Paul II objected to institutional setups that reduced workers to a sort of merchandise, downgrading workers to the level of inanimate beings. ${ }^{4} \mathrm{He}$ commented on work situations when employers took better care of their investments, like modern equipment, and cared less for their workers. For John Paul II, it is a self-evident principle that a human person must enjoy priority over things. The worker, gifted with a spiritual soul, with intelligence and free will, cannot but be over and above inanimate material things. The business profit earned could not have been realized without the participation of labor. All the means used to create profit were conceived and made by labor. No one else but the human person who provides the services runs the machinery and makes the technological equipment work.

There is a principle in philosophy that states: "He who causes a thing is the owner of the thing." The human person alone is the responsible author and cause of added wealth. Since wealth is caused principally by the labor of the workers, then the workers, big and small, must be part-owners of that wealth. Just wage rightly belongs to each worker. As defined in the encyclical, just wage must be enough to support the worker and his family. The profitability of a business should affect the scale of wages. The wage scale must have the economic welfare of all people in mind. This principle is violated when business operation expands amid the practice of inhuman and depersonalizing work conditions such as prolonged contractual services. One should be bothered when an enterprise owner exhibits wealth but fails to ensure just wage for the workers by sub-contracting to agencies. It would be right to implicate the business for neglecting to uphold the welfare of their workers.

\section{The Human Person's Self-Making In and Through Work}

Human work constitutes the axis of human self-making and self-realization. The ethical meaning of work is found in this truth: Despite the toil, work is a good thing for man: not only is it a worthy and useful good, but it also corresponds to man's dignity and expresses and increases (LE No. 9). The human person also works in order to achieve perfection. Work is thus an instrument or tool of the human being. Work is for the human person and not the human person for work.

According to John Paul II in the Laborem Exercens, we self-realize and selffulfill ourselves in and through work in four areas of work relationships: 1) the Person-Work Relationship, 2) the Person-Work-Family-Society Relationship, 3) the Person-Work-Nature Relationship, and 4) the Person-Work-Creator Relationship. Let me elaborate on the first three areas of work relationships.

1) The Person-Work Relationship. Laborem Exercens emphasized that work is good for the human person. It strengthens our muscles and our memory, among others. It explains why many senior citizens do not like to retire. They are afraid of 
boredom, early mental decline, and losing purpose in life. Work is a good thing for humanity. It is through work that nature is transformed and adapted to human needs, and the human person also achieves fulfillment and, in a sense, becomes a fuller human being. We confirm this in people who work with pleasure and dedication, like some animal rescuers or community volunteers. We experience it when we take care of our children or aging parents. In and through work, we grow fuller in perseverance, patience, and love.

2) The Person-Work-Family-Society Relationship. Beyond the personal dimension, Laborem Exercens speaks of work in its social aspect, stressing its value for both the family and the nation. It is through work that human beings provide for their families' needs. Unless one is born with an unconsumable inheritance, for most of us, work is important to buy food, shelter, and education. Besides, by the example of their work, parents educate their children, making them appreciate the necessity and nobility of work. Children inherit their parents' work ethics. Work is essential to the nation, for, through the work of its citizens, nations get rich. The prosperity of a nation embodies the work of generations.

3) The Person-Work-Nature Relationship. The mastery over the world that God offered the person from the beginning was realized above all within himself: mastery of self. "Subdue the earth and have dominion" (Genesis 1:28). The earth is entrusted to the human person, and through work, the person has dominion over it. The whole effort to acquire knowledge of nature teaches us that everything that comes from the human person in economic production is resources that a person finds but does not create. "The human person finds the gifts of nature, of the creator, really prepared for the person to discover and use, and so at the beginning of the human person's work is the mystery of creation" (LE No. 12).

In Baum's words (1986, 233), “Through labor people create their world, their social world, and in doing so, they in some sense create themselves." The human person defines himself in and through work.

\section{The Acting Person and Morality}

Work is a personal action. The one who carries it is a person, a conscious and free subject. Actions can be good or bad, right or wrong, or neither. John Paul II maintains the principle that only actions that are morally good can be self-fulfilling. Morality is an important consideration in this quest for self-fulfillment through work. There is an inherent interrelationship between the human person and his action. Depending on whether the act is good or evil, a person becomes morally good or evil through one's act. As discussed in detail by Aguas $(2013,135)$ :

The person fulfills himself when he performs an action that is good, a true good, a good that is in accord with a true and good conscience. When the object of choice is a true good, then the human action is good, and when the object of choice is a false good, then the human action is bad or evil. The human person consequently becomes good or evil, depending on the morality of his actions. Thus, the moral value of the act reaches the very depths of the human person. Self-fulfillment 
depends on the fulfillment or performance of a truly good act. When a man performs an act, he at once actualizes himself in action, and as a human person, he becomes either good or evil depending on the moral value of the act performed. It follows that truth and goodness have a decisive influence on the formation of the subject and the total development of the person as revealed through the analysis of conscience and morality. In particular, the moral formation of the human person means a formation through moral good; the human person is formed through moral good.

\section{APPROPRIATION: THE TEACHER AS A WORKER AND ACTING PERSON}

\section{Teaching is a Creative Work}

Teaching is not just a job, an assignment, or a profession but also a mission, a passion, or even a calling. Teaching allows one to exercise creative powers in order to equip students with the necessary skills, knowledge, and attitude for human flourishing. Teaching work involves being rational. Teaching is a human act. Only humans are capable of teaching, whether in person, online or in distance learning. The teacher's credibility and effectiveness among students, affirms the teacher's dignity. Teaching humanizes because education enables and empowers. Teaching transforms students into persons that will address various human needs. Progress in technology and social media cannot totally eradicate the work of teachers.

\section{Teaching is Solidarity Work}

Teachers prepare students to contribute to society through the life work they choose. Teachers help students improve their chances to thrive in whatever enterprise they engage in, consequently enabling them to build their respective families. Teaching, advising, mentoring, coaching, leading, and consulting are works for the common good. A teacher essentially works for and with others.

Teachers directly influence the progress of society. A teacher shares the knowledge, wisdom, and understanding necessary to help and build others' lives. It is a noble profession of giving what one has. It enables others to achieve what they dream of. Teachers co-produce good priests, doctors, lawyers, engineers, scientists, economists, nurses, farmers, technicians, janitors, domestic helpers, taxi drivers, security guards, bank tellers, vendors, carpenters, builders. Regardless of one's profession, everyone benefited from being taught by teachers.

\section{A Teacher is a Symbol of Dignity, Pride, and Honor}

The teaching profession is among the sacred professions carrying divine inspiration and protection. It is a demanding career in terms of selflessness, service, commitment, and sacrifice. Some people approach their work only as a necessary part of the habitual and sometimes almost mechanical daily living routine. But teaching cannot be merely a routine as teachers are part-makers of future generations 
of leaders and parents, each having their unique makeup and challenges. In that way, teachers are the mentors of society and architects of the nation. Think of the role of Socrates to Plato, then of Plato to Aristotle.

\section{Teaching as Participation}

The teacher participates by sharing talent, skills, and experiences. In John Paul II's analysis of the person, experience is the starting point of knowledge (Mejos 2007, 72). Capturing that richness of the human person in words does not come naturally. The experience of man needs deliberate mindfulness. This deliberate mindfulness of experience, of existing and acting together with others, is key to participation.

I maintain that continuous teaching, learning, and re-learning translates to a teacher's personal growth (Macaranas 2018). Teachers must also grow in the habit of standing up for values, for values form the core of the knowledge they impart on the young people entrusted to them. One cannot give what one does not have, as the saying goes. It entails the perfection of being and self-actualization. This is affirmed by Ferdinand Tablan $(2015,292)$, who expounded on how work is not only instrumental in humanizing nature but also in humanizing man. Importantly, "work is man's species activity, i.e., it is not only an act of man but also his self-activity."

Indeed, reflecting on one's experience is a worthwhile effort. It is the antidote to alienation from one's work. The insights and the external validation gathered in the process are worth the challenge (Macaranas 2017). A teacher's examined life, no matter how the struggle is, becomes worth living. A worker finds fulfillment in the process of meditating on one's experiences. The act and habit of sharing and imparting experiences make the teacher an agent against alienation.

\section{CONDITIONS THAT DEHUMANIZE TEACHERS}

The dignity of the profession is not always reflected in the earnings, but more by what values and standards they stand for. Many teachers work in difficult situations with competing priorities. Overworked and stressed, the physical and mental health problem is becoming common among them. Despite salary standardization in public schools, many teachers are paid low and lack work security. Teaching well, especially in private schools, does not secure one's job. They are saddled with bureaucratic and burdensome paper requirements. Teachers are not spared from budget cuts. The cheaper the salary, the better for a private school's budget to afford expansion in buildings, acquisition of modern facilities, and accommodate more students. In the business of education, the teaching workforce, like other workers, is just a budget item.

Teaching is not a lucrative job. In order to fully support their family, some shuttle between schools. Some eventually leave teaching to seek higher income by building their own business, working in call centers, or working abroad as domestic helpers or nannies. Due to the persistent unemployment problem, some remain to teach but without enthusiasm. They just teach for the sake of teaching. It merely pays the bills. 
Teachers serve as workers and real agents of production in education. Work is the labor of an acting subject; it helps to view labor in relation to its "partner in modern production, capital" (Finn, 2012, 876). Labor having priority over capital is a basic principle in Laborem Exercens. According to Finn (2012, 874), "the ablebodied have a moral obligation to work to obtain the things they need, but everyone has a claim on the necessities of life."

The following fictional $\operatorname{cases}^{5}$ describe some of the challenges facing the teachers at work.

\section{A Professor's Dilemma}

A university professor shared this story. The school does not need me anymore. Our dean told me that my contract would not be renewed this coming term. I do not want to tell my wife and children that I lost my job. I cannot find another job that pays as well as the school. I do not know what to do with my time. I am glad that some students need help with writing their papers. One offered me a good price just to write for him. For the sake of my family, I am seriously considering accepting the job.

Then, he asked, "If you were in my shoes, would you grab such an opportunity?"

This case illustrates the plight of contractual teachers. Teachers need just wages and humane work conditions. The lack of it pushes them to look for other sources of income, whether on a long-term or short-term basis, to tide them over in between jobs. But then, work in education, whether teaching or allied services, must be evaluated to be considered the right supplements or alternatives. Teachers must realize that only moral actions can be self-fulfilling. Maintaining one's moral integrity is central in keeping the ability to help students accomplish their work as students. The situation can motivate them to provide extra services to students. However, doing what students ought to do themselves for a fee is like selling education. Earning one's education loses its meaning and dignity. One's inability to navigate the dire situation in a healthy and dignified manner will lead to losing one's moral ascendancy as an educator. Teachers must model Dignity-promoting work habits and culture.

On the part of the school and government administrators responsible for hiring and paying teachers, they have the moral responsibility to support teachers with job security and pay fitting for the honorable job that teachers do (LE, No 17, 19).

\section{BC Tasyo, the Busy Man}

BC Tasyo is a working student. He earns his tuition fee by doing projects, assignments, and thesis papers for other students. To be able to accomplish and earn more, he plagiarizes by copying others' works. Moreover, because he is busy, he hardly finds time to study. To pass his exams, he cheats. When needed, he gives gifts to professors to avoid failing. Is BC Tasyo an acting person as described by John Paul II? 
Teachers meet multiple versions of BC Tasyo. Young and enterprising students need guidance and counsel from teachers that only moral actions can be self-fulfilling. Only through honest work does the human person find fulfillment realization to the fullest. It is the teacher's duty to be vigilant in observing how they work, to review their submissions, to conscientize on intellectual honesty, and to personally design and administer exams to discourage cheating. Uncorrected, BC Tasyo's survival strategy would become his lifestyle. Teachers are in the best position to catch this tendency and prevent its spread in the school and society. As persons, they can influence and accompany students, instructing them on the dignity of work.

\section{Pepe, the Grade-Conscious}

Pepe is a nice student, well-behaved, dependable, and diligent. He has a good academic performance. His only motivation is to get high grades and the approval of teachers. He is so focused on his goals that he does not interact much with his classmates.

Should a teacher encourage students to focus on grades only? There are measures that would encourage students to find varied sources of fulfillment in the course of their studies. Work is a means to participate and be in solidarity with others. Giving learning opportunities that challenge Pepe's social skills and other attributes and potentials would equip Pepe to care and to thrive with others in the real world. Allowing him to pay too much attention to grades is like giving him false hope that a good life can be carved alone. His narrow-mindedness would blind him to the various relationships that he must consider in accomplishing work, whether it is a business, a program, a project, or a simple task. A loose translation of this lifestyle would be an employer who defines success by the income one gets, regardless of the environmental or social impact of one's trade.

\section{Pilo, the Excused Student}

Pilo is an average student in most subjects and is especially doing poorly in philosophy. He often turns in unfinished assignments and avoids taking down notes. He occasionally spends the philosophy period in the clinic: complaining of a headache, lack of sleep, or dizziness that justifies resting during his Philosophy class.

How can a teacher help Pilo improve his life as a student? Work avoidance limits one's self-realization and self-fulfillment. So does mediocrity in work. Perhaps he is in the wrong course or school. Alternatively, perhaps, he has a family problem. Part of a teacher's daily life involves meeting students and discovering their unique circumstances that sometimes overburden their young minds and weaken their resolve to explore or bravely face their challenges. Getting to know them and helping them out of their rut gives one a chance to move each student to truly work and enjoy their studies. A teacher's personal and authentic attention can be pivotal in awakening a student's potential and uniqueness that would otherwise remain hidden. 


\section{Sophia, "the Gimmick Kid"}

Sophia is frequently absent. She goes to school more to see her friends than to attend classes. Most of her friends have a similar attitude toward their studies. They do a lot of fun things. They eat out and visit hip places, do interactive video games, etc. Running out of things to do, they already tried drugs, smoking, and drinking. Now, when Sophia manages to attend class, she is late and sleepy.

What is a teacher's duty to Sophia? Should a teacher let her be? Should a teacher respect her decision to do as she wishes and allow her to experience school failure to teach her a lesson? Indeed, the teacher's daily work is beyond classroom teaching. Sophia typifies a lost student needing direction as she seeks distractions. Teaching is a mission. Accompanying Sophia and putting her back on track would require collaborating with her family and other offices in the school. In such circumstances, teachers step up as the student's second parent.

Indeed, correcting one student at a time, inspiring a whole class to outdo their previous best, or cheering up one discouraged soul back on track, could keep the teacher occupied inside and outside the classroom. Such is the ordinary life of a teacher. Such works could never be fully documented or captured by any writer as the teacher may not even realize it in the performance of his/her daily task. However, everybody who has been a student would recall at least one good teacher who did something so crucial that it boosted his or her student life.

Some of the best teachers also get recognized by a whole class, recounted during reunions or meetings after school, often not communicated to the teacher him/herself. The contributions of good teachers only dawn on their students later in life. Certainly, the dignity of teachers gets carved into the successful and happy lives of their students. It is society's duty to give back to teachers and ensure their just wages and humane working conditions. Teachers and their families deserve a good life.

Teachers need to have a strong resolve to teach and maintain a dynamic view of one's themselves at work. Aside from continuous learning and re-learning, they need to be in a dialogical stance. Reading books, such as Dialogue and Boundary Learning (Rule 2015), enriches one's work appreciation. Rule presented six senses of dialogue, namely: dialogue as talk, literary dialogue, dialogue as mutual engagement, dialogue as being, dialogical self, dialogue, and learning (Macaranas 2020,291 ). Teaching in the context of dialogue leads to loving your work. ${ }^{6}$

The encyclical points out that "man's work is both a destiny and a calling," and emphasizes that work is "for man," not man "for work" (LE, No. 6 as cited by Gaburro, Giuseppe and Giancarlo Cressotti 1998). In other words, man's duty is to work, not only to produce and possess but also to achieve fulfillment. The human person must be the ultimate aim of any entrepreneurial activity. Work in education is not exempted from this principle. Over and above, the creation of economic value is the promotion of the dignity of the human person, the teacher. 


\section{CONCLUSION}

Our humanity must be evident in our work. John Paul II has indeed fashioned a philosophy that profoundly articulates the inseparability of the dignity of person and work. John Paul II invited everyone to examine the philosophical, theological, spiritual, and ethical dimensions of work. For him, a proper understanding of work is the door to solving all social problems. ${ }^{7}$

An educator's work is a daunting task. The primacy, nature, and dignity of the teacher are founded on being the subject and doer of work. Pedagogical work is not just a job; it is a venue for self-fulfillment. Teaching is a mission. As a subject, the worker-teacher can find fulfillment and self-realization to the fullest. Through pedagogy, the teacher can perfect him/herself in solidarity and participation with others. Indeed, in teaching, there is always a glimmer of new life in which teachers participate precisely through the toil that goes with work.

\section{NOTES}

1. Also, see Laborem Exercens: Encyclical Letter addressed by the Supreme Pontiff John Paul II on Human Work on the Ninetieth Anniversary of the Encyclical Rerum Novarum. 1993. Pasay City, Philippines: Daughters of St. Paul. Also, Laborem Exercens at http://www.vatican.va/content/john-paulii/en/encyclicals/documents/hf_jp-ii_enc_14091981_laborem-exercens.html. Libreria Editrice Vaticana.

2. The fundamental question about the human person is a question that has fascinated humanity. There are numerous philosophical perspectives or views on understanding the nature of the human person. The personalist view is just one of them. It is interesting to note that Karol Wojtyla enrolled at the Angelicum University, where he studied Thomistic philosophy under the tutelage of the great known Thomist Prof. Reginald Garrigou-Lagrange. Thus, Thomism would be one of the important influences in the thought of Karol Wojtyla. Another significant influence in his thought is Max Scheler. The irreducible uniqueness of human and humanizing emotions was central in Max Scheler's philosophy. Through Scheler, he was also influenced by Edmund Husserl's phenomenological method. (See Peter Hebblethwaite. 1994. The Man who became Pope John Paul II. London: Collins Publishers. pp. 12-13).

3. His philosophy on the human person has been laid down since his first encyclical Redemptor Hominis (1979). Laborem Exercens goes back to this philosophy in the context of work.

4. Laborem Exercens was written at a time when debates between capitalism and communism were at the forefront. For one, the encyclical singled out the capitalist practice of buying labor in the same manner that they buy the raw materials and the types of machinery needed for production, which he found inappropriate as it strips workers of their dignity as a human person. For broader applicability of the principles, this paper will use less political terms and adopt a more general language in discussing the wage issue. 
5. Case scenarios were used, mainly to illustrate problems that call for reappropriating John Paul II's philosophies. The cases were based on real-life experiences of teachers and students in work that the author directly observed or has adapted from other exercise materials. Names were changed to fictionalize the characters. Some of the reflective questions posed during the presentation were retained. They were given to encourage participation among the lecture audience.

6. Dialogue and Boundary Learning can help teachers enrich their philosophy of education, which is a key ingredient to having a fulfilling teaching life. The review that I wrote on this book summarizes its key points. The book makes a persuasive case for a dialogical account of learning. Accordingly, dialogue is the key to boundless learning. The book engages readers to a full intellectual engagement, allowing them to reflect on their academic life (Macaranas 2020, 296).

7. It is interesting to note that John Paul II's philosophy is sympathetic with the Marxist perspective, which views a human person as a homo faber or a working being. As highlighted by Tablan $(2013,181)$, the Marxist perspective holds that "...through work, man realizes and confirms his authentic nature. Work acts as the mediator between man and nature, man and the social world, and man and his species. It is work which relates the different components of human life, which would otherwise disintegrate on account of tensions and conflicts arising from the concrete circumstances of one's daily living." This challenges me to further research on this connection.

\section{REFERENCES}

Aguas, Jove Jim S. 2014. Person, action and love: The philosophical thoughts of Karol Wojtyla (John Paul II). Manila: University of Santo Tomas Publishing House.

Aguas, Jove Jim S. 2013. Ethics and moral philosophy of Karol Wojtyla. Kritike 7 (1): 115-137. https://doi.org/10.25138/7.1.a.7.

Aguas, Jove Jim S. 2009. The notions of the human person and human dignity in Aquinas and Wojtyla. Kritike 3 (1): 40-60. https://doi.org/10.25138/3.1.a.4.

Baum, Gregory. 1986. John Paul II's Encyclical on Labor. Readings in moral theology, no. 5. Official catholic social teaching. Edited by Charles Curran and Richard McCormick. New York: Paulist Press.

Catholic Church. 2005. Pontificium consilium de iustitia et pace: Compendium of the social doctrine of the church. London: Burns \& Oates.

Catholic Charities USA. 1987. The social teachings of Pope John Paul II: Presented to his holiness Pope John Paul II. Social thought, V. 13, No. 2/3, Washington, DC: Catholic Charities USA.

Curran, Charles and Richard McCormick, eds. 1986. Official catholic social teaching. Readings in moral theology, no. 5. New York: Paulist Press.

Doyle, Thomas. 1987. The Dignity of the Human Person in the thought of John Paul II. In Social thought: the social teachings of Pope John Paul II. Edited by Dorothy A. Mohler. Washington DC: Catholic Charities USA.

Finn, Daniel. 2012. Human Work in Catholic Social Thought. American journal of economics \& sociology. Oct 2012, Vol. 71 Issue 4, 874-885. 
https://independent.academia.edu/DanielFinn2. Accessed: December 15, 2020.

Gaburro, Giuseppe and Giancarlo Cressotti. 1998. Work as such - the Social Teaching of the Church on Human Work. International Journal of Social Economics 25, no.

11:1618-39.

https://search.proquest.com/docview/274632024?accountid=190479. Accessed: February 20, 2020.

Hebblethwaite, Peter. 1994. The Man who became Pope John Paul II. London: Collins Publishers.

John Paul II. 1993. Laborem exercens: Encyclical letter of the supreme pontiff on human work. Pasay City, Philippines: Daughters of St. Paul.

John Paul II. 1981. Laborem exercens. Libreria Editrice Vaticana. http://www.vatican.va/holy_father/john_paul_ii/encyclicals/documents/hf_jpii_enc_14091981_laborem-exercens_en.html. Accessed: February 20, 2020.

John Paul II. 1979. Redemptor hominis. Libreria Editrice Vaticana. http://www.vatican.va/content/john-paul-ii/en/encyclicals/documents/hf_jpii_enc_04031979_redemptor-hominis.html. Accessed on 20 February 2020.

Lawler, Ronald. 1982. The Christian personalism of Pope John Paul II. Chicago: Franciscan Herald Press.

Macaranas, Juan Rafael G. 2020. Book Review: Dialogue and boundary learning by Peter Neville Rule. Philosophia International Journal of Philosophy, 21 (2): 291297. doi.org/10.46992/pijp.21.2.r.1 https://c4fb26e2-a44c-4aea-96c2-

74fd10a43d0e.filesusr.com/ugd/dcdc59_eb222d03374441658cf6240a5a5ace62.p df

Macaranas, Juan Rafael G. 2018. Growth in learner-centered pedagogy. Philosophia: International Journal of Philosophy, 19 (2): 163-172. https://www.pnprsphilosophia.com/2018mayvolume19no2. Accessed: December 15, 2020.

Macaranas, Juan Rafael G. 2017. Teaching logic: An examination of a classroom practice. Philosophia: International Journal of Philosophy, 18 (2): 222-240. https://c4fb26e2-a44c-4aea-96c2-

74fd10a43d0e.filesusr.com/ugd/dcdc59_eaa82e797d514293ab43e33c3f8606e8.p df Accessed: December 15, 2020.

Mara, Peter Emmanuel A. 2007. Understanding man as a subject and a person: A Wojtylan personalistic interpretation of the human being. Kritike (1): 86-95. https://doi.org/10.25138/1.1.a.6.

Mejos, Dean Edward A. 2007. Against alienation: Karol Wojtyla's theory of participation. Kritike (1): 71-85. https://doi.org/10.25138/1.1.a.5.

Rule, Peter Neville. 2015. Dialogue and boundary learning. Rotterdam: Sense.

Szulc, Tad. 1996. Pope John Paul II: The biography. New York: Pocket Books.

Tablan, Ferdinand. 2015. Catholic social teachings: Toward a meaningful work. Journal of Business Ethics $128 \quad$ (2): 291-303. https://bellevuecollege.academia.edu/FerdinandTablan. Accessed: December 15, 2020.

Tablan, Ferdinand. 2013. Meaning and value of work: A Marxist perspective. Philosophia International Journal of Philosophy, 14, (2): 169-185. https://www.pnprs-philosophia.com/archive2013. Accessed on 15 December 2020. 
Vatican Council II, 1965. Gaudium et spes.

http://www.vatican.va/archive/hist_councils/ii_vatican_council/documents/vatii_const_19651207_gaudium-et-spes_en.html. Accessed: February 21, 2020.

Vatican Council II, 1965. Dignitatis humane. http://www.vatican.va/archive/ hist_councils/ ii_vatican_council/documents/vat-ii_decl_19651207_dignitatishumanae_en.html. Accessed: February 21, 2020.

Weigel, George. 2005. Witness to hope: The biography of Pope John Paul II. New York: Harper Perennial. 